\title{
ON THE VALENCY OF VARIOUS TYPES OF ADVERBS AND ITS LEXICOGRAPHIC DESCRIPTION
}

\author{
JAKUB SLÁMA - BARBORA ŠTĚPÁNKOVÁ \\ Czech Language Institute of the Czech Academy of Sciences, Prague, Czech Republic \\ Charles University, Prague, Czech Republic
}

SLÁMA, Jakub - ŠTĚPÁNKOVÁ, Barbora: On the valency of various types of adverbs and its lexicographic description. Journal of Linguistics, 2019, Vol. 70, No 2, pp. $158-169$.

Abstract: This paper deals with the neglected issue of the valency of adverbs. After providing a brief theoretical background, a procedure is presented of extracting the list of potentially valent adverbs from two syntactically parsed corpora of Czech, SYN2015 and PDT. Taking note of the methodological and theoretical problems surrounding this task, especially those relating to the fuzzy boundaries of word classes, we outline the types of adverbs identified as having valency properties. Where appropriate, we comment on - and occasionally suggest improvements in - the lexicographic treatment of valent adverbs.

Keywords: adverbs, valency, dictionary, syntactically parsed corpora, Czech

\section{INTRODUCTION}

Valency is undoubtedly a central topic in syntax and "a primary concern of all approaches to the grammar of human languages" [1, p. 39]. As Spevak [2, p. ix] puts it, however, the valency of nouns has remained "in the shadow of the valency of verbs," and the same arguably applies to the valency of adjectives, and to an even more serious extent to the valency of adverbs, which is only occasionally paid lip service to but remains conspicuously underresearched. We therefore provide an overview of how the notion of valency has broadened to cover not only verbs, and of what has been written about the valency of adverbs in Czech. Then we propose a way of extracting a list of potentially valent adverbs from syntactically parsed corpora of Czech, and we outline the types of adverbs which appear to have valency properties, touching upon some problematic points concerning the fuzzy boundaries of linguistic categories (cf. for instance [3, pp. 568-570]), and, where appropriate, commenting on the lexicographic description of the adverbs under discussion. 


\section{THEORETICAL BACKGROUND}

\subsection{The scope of the notion of valency ${ }^{1}$}

Valency can be delineated as "the capacity a verb (or noun, etc.) has for combining with particular patterns of other sentence constituents" [5, p. 301]. Tesnière [6, p. 670] famously defined valency as "nombre d'actants qu'un verbe est susceptible de régir", i.e. as a property of verbs. The very next year saw the publication of an early transformational generativist account of nominalizations, which includes some interesting observations on the valency of nominals [7, pp. 6673]. However, it was only later that it began to be widely recognized that valency is not restricted to verbs; for instance, Matthews [8, p. 115] - still somewhat cautiously - states that adjectives can also have "semantic properties akin to valency." Over a decade later, Matthews [9, p. 394] defines valency as a property of "a verb or other lexical unit." This is in accord with a more general trend towards admitting lexical units other than verbs into the description of valency, which resulted in valency being redefined generally as "the number and type of bonds which syntactic elements may form with each other" [10], which, according to Matthews [11, p. 4], suggests that valency should not be the foundation "just of the syntax of verbs, or of verbs and other lexical units, but of syntax generally". Nevertheless, the valency of adverbs is still a rather neglected area: for instance, couched within the Pattern Grammar, there is a two-volume grammar of the patterns for verbs [12] and nouns and adjectives [13], with adverbs not attended to. On the other hand, the database FrameNet does include some adverbs, whereby, however, these are only said to evoke frames (e.g. the adverb in Bill wisely sold the piano is said to evoke the Mental property frame), which hardly amounts to postulating a valency frame for such adverbs.

\subsection{The valency of adverbs in Czech linguistics}

Adverbs in Czech have been noted to have valency properties; Karlík \& Biskup [14] give the example of nezávisle (Jednal nezávisle na rodičích. 'He acted independently of his parents'), while noting that the Czech grammatical description has largely neglected the valency of adverbs. Panevová $[15$, p. 7] briefly mentions the valency of adverbs when noting that we have to acknowledge not only that deadjectival adverbs might have valency properties, but also that primary, nonderived adverbs might require obligatory complements, giving the example of daleko 'far', to which she applies the question test: Je to daleko. Odkud (od čeho)? *Nevím. lit. 'It is far. From where? *I don't know.'

In older Czech dictionaries, derived adverbs are not provided with entries of their own; they are nested with their adjectival bases. For instance, in Slovnik spisovného jazyka českého, nezávisle is nested in the entry for nezávisly' 'independent', whose

\footnotetext{
${ }^{1}$ Parts of this section are loosely based on [4, esp. 2.2.1].
} 
colligation (na kom, čem 'of sb, sth') is nevertheless listed in the entry. It is assumed that the adverb can take complements with the preposition $n a$ followed by a locative form as well, as shown by the example given (vznikat nezávisle na něčem 'arise independently of'). In Akademický slovník současné češtiny (hereafter ASSČ) ${ }^{2}$ deadjectival adverbs have their own entries [16, p. 123], and so they might have - as the only type of adverbs [16, p. 68] - their own valency specification (nevertheless, the dictionary does not list only obligatory complements but also typical modifiers, without the two being explicitly distinguished). Thus, for instance, the adjective bezohledny' 'reckless' and the adverb bezohlednè 'recklessly' have (ke komu, $k$ čemu; viči komu, viči čemu 'with sb, sth; to sb, sth') listed as their complements.

\section{DATA \& METHODOLOGY}

In an attempt to arrive at as complete a list of valent adverbs in Czech as possible in a way as objective as possible, we decided to rely on the two syntactically annotated corpora of Czech available, i.e. the automatically parsed SYN2015 of the Czech National Corpus project and the manually annotated Prague Dependency Treebank (PDT). In order to find valent adverbs we searched for nodes whose parent nodes are occupied by adverbs.

\subsection{SYN2015}

In the corpus SYN2015, we used the following query:

$1:[\operatorname{tag}=" D . * "][]\{0,5\} 2:\left[p_{\text {tag }}=" \mathrm{D} . * "\right]$ \& 1.lemma=2.p_lemma within $<_{\mathrm{S}} />$

The results were then checked manually. Tagging and parsing errors were excluded, including, for instance, the following:

(1) Efekt chyb DNA na př́padný vývoj nemocí v mozku je také jednou z oblastí, která bude v hledáčku. ${ }^{3}$ [jednou mistagged as an adverb]

'The effect of DNA errors on the possible development of diseases in the brain is also one of the areas which are going to be monitored.'

(2) Učenci jsou vlídní a přivětiví, hledají, jak být užiteční bližním i jak přispět $k$ obecnému blahu. [jak parsed as the parent node of $i$ ]

'Scholars are kind and friendly; they are looking for ways how to be helpful to their fellows and how to contribute to the public good.'

Similarly, we excluded concordances in which there is a terminal punctuation mark between the node and its alleged daughter. Next, we excluded concordances in which the adverb seems to have a complement, but this dependent is part of a larger syntactic construction, most notably the comparative construction:

\footnotetext{
${ }^{2}$ See $<$ http: //www. slovnikcestiny.cz>.

${ }^{3}$ Unless explicitly stated otherwise, the examples come from SYN2015.
} 
(3) nikdo neumí tabuli umýt tak dokonale jako já 'no one can clean the blackboard as perfectly as me'

Similarly, we excluded other comparative constructions and similes, as in (4). Furthermore, we excluded expressions that can be classified as secondary prepositions, e.g. včetně (5), linking adverbials, e.g.jmenovitě (6) and resp. (7), quantity expressions, e.g. hodně (8) and drahně (9), and particles, e.g. samozrejemě (10) and už (11):

(4) Pližžǐs se po domě tiše jako kočka a já si toho hned všimnu.

'You are creeping about the house as soundlessly as a cat and I immediately notice that.'

(5) Z celého Izraele bylo prijato pouze dvacet čtyři lidí včetně Suzany. 'Of the whole of Israel only 24 people were accepted including Suzane.'

(6) Velké šelmy, jmenovitě tygři, na ostrovy nepronikly. 'Big cats, namely tigers, did not reach the islands.'

(7) je nežádoucí, resp. nepotřebný 'he is undesirable, or rather useless'

(8) Jezte hodně vlákniny. 'Eat a lot of fibre.'

(9) Tři dny mě vídal, je to drahně let. 'He was seeing me for three days, it's been many years.'

(10) Samožrejmě peněz by mohlo a mělo být více.

'Naturally there could, and should, be more money.'

(11) Už měsíce ji uháněl, aby s ním šla na skleničku...

'He's been trying to get her to go out for a drink with him for months.'

Finally, we naturally excluded words that can be considered adverbs, but that cannot be deemed to have valency (such as francouzsky, krátce, and maloplošně in (12)-(14)):

(12) musíme udèlat nádivku (francouzsky farce) 'prepare the stuffing (farce in French)'

(13) Za svou snahu však byl odměněn krátce před pauzou. 'was however rewarded for his efforts shortly before the break.'

(14) Celek je chráněn maloplošně jako PR Kř́žzová cesta a je součástí CHKO Broumovsko.

'The whole is protected on a small-scale as the Nature Reserve Křížová cesta and is part of the Broumovsko Protected Landscape Area.'

Overall, we discarded hundreds of adverb candidates: the initial list of parent adverbs in SYN2015 included 1810 words tagged simultaneously as adverbs and parent nodes at least in three instances. 


\subsection{PDT}

In the PDT, we used the following query:

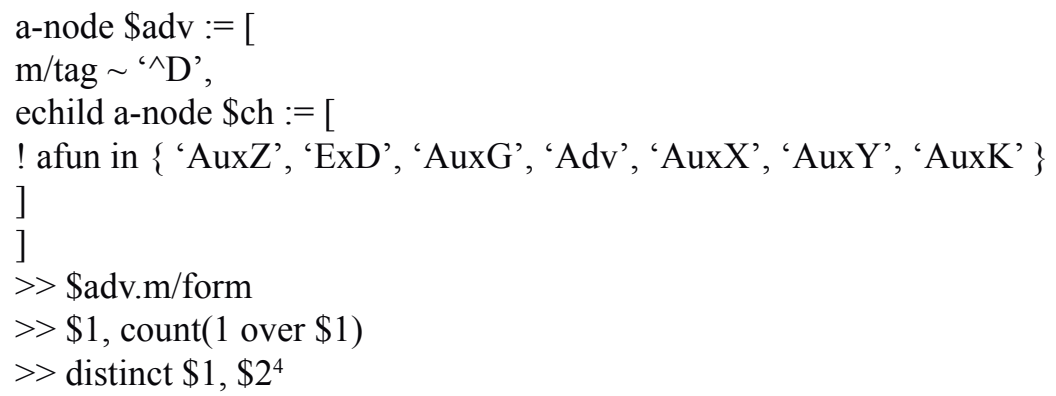

The results include adverbs that function as parent nodes for auxiliary nodes, e.g. apod, which is always the parent of a node corresponding to a full stop. Moreover, the query results included adverbs in coordination with another adverb yet without any complement; these results were naturally excluded as well (including e.g. citlivéji 'sensitively' in obezřetněji a citlivěji 'more carefully and sensitively'). Another group of cases that were discarded includes foreign language expressions, such as memoriam in in memoriam (with in parsed as a dependent of memoriam), and words mistagged as adverbs, such as ostrožně in Jeruzalém byl postaven na ostrožně Chrámové hory 'Jerusalem was built on the promontory of the Temple Mount'. We also excluded instances in which there is a dependent of the adverb under scrutiny, but this dependent functions as a modifier rather than a complement (e.g. zcela běžně 'quite routinely' with běžně as the parent node). Finally, we also excluded cases such as the following, in which it is clear that the word in bold cannot be deemed a valent adverb:

(15) A právě ono $\boldsymbol{k d y}$ vám dokážeme ř́ci.

'And we are able to tell you just this when.'

(16) Jinak - a řekněme hned, že mnohem hůře - je na tom čtenár denního tisku.

'The reader of the daily press is doing differently - and let us say straight away that much worse.'

(17) Piloty jsou zaberaněny shora dolů do bažiny...

'Stilts are stuck from above down to the swamp.'

This produced a list of only nine potentially relevant adverbs, all of which were also arrived at when working with SYN2015, viz. the predicative adverbs lito 'sorry' and oblačno 'cloudy', and the adverbs přiměreně 'adequately', nezávisle 'independently', stejně 'just (as)', západně 'west', úměrně 'proportionately', blízko 'near', and daleko 'far'.

${ }^{4}$ The query can be executed at $<\mathrm{http}$ ://lindat.mff.cuni.cz/services/pmltq/\#!/ treebank/pdt30/query/>. 


\section{RESULTS}

The results included various types of adverbs, which we discuss one by one in the following sections. In each section we give examples which should be clearly indicative of why we consider the respective adverbs to be valent. For instance, kolmo 'perpendicularly' is included in the second section with the following example:

(18) Holeně zůstávaji kolmo $k$ zemi, chodidla umistěte na šiřku kyčelních kloubů.

'Keep your shins perpendicular to the ground, and place your feet straight below your hips.'

Since we consider (18a) and (18b) not to be simultaneously acceptable and equivalent in meaning to (18), kolmo is a valent adverb in our view:

(18a) *Holeně zůstávaji kolmo, chodidla umistěte na šiřku kyčelních kloubů.

'Keep your shins perpendicular, and place your feet straight below your hips.'

(18b) *Holeně zưstávaji k zemi, chodidla umistěte na šiřku kyčelních kloubů.

'Keep your shins to the ground, and place your feet straight below your hips.'

\subsection{Deadjectival adverbs typically used as adverbials}

This group includes several adverbs that can be grouped semantically as follows:

a) adverbs expressing spatial relations (with possible metaphorical semantic extensions): kolmo 'perpendicularly', paralelně 'paralel', rovnoběžně 'parallel', nalevo 'left', napravo 'right', vlevo 'left', vpravo 'right', vodorovně 'horizontally', symetricky 'symetrically', príčnè 'diagonally'

(19) Vleče mě to stranou, paralelněs pobřežím, př́mo do cesty jachty hnané větrem. 'It's dragging me aside, parallel to the coastline, straight in the way of a yacht driven by the wind.'

(20) Umistil jej v blizkosti hlavní brány, vlevo od př́jezdové cesty.

'He placed it nearby the main gate, to the left of the driveway.'

(21) Symetricky k očekávání budoucnosti existuje podle našeho soudu rovněž "očekáváni minulosti".

'Symetrically to the future expectations there exist, in our view, "past expectations".'

Other potentially valent adverbs (esp. daleko 'far', blizko 'near', and nablizku 'close') were discarded as prepositions, cf. [17, pp. 39-40].

b) directional adverbs requiring a complement with the preposition od followed by a genitive form: jižně 'south', severně 'north', západně 'west', východně 'east', 
jihovýchodně 'southeast', jihozápadně 'southwest', severovýchodně 'northeast', severozápadně 'northwest', jihojihovýchodně 'southsoutheast', západoseverozápadně 'westnorthwest'

(22) Západně od věže máme kostel svatého Martina s okolními stavbami.

'West of the tower there is the church of Saint Martin with the surrounding buildings.'

c) adverbs of comparison: analogicky, odlišně, relativně, proporčně, protikladně, srovnatelně

(23) pojímá diskusi radikálně odlišně od všech předřečníků (SYN V7)

lit. 'he conceives of the discussion radically differently from all the previous speakers'

(24) ČSSD i ANO hlasovaly protikladně ke svým opakovaným veřejným proklamacim (SYN V7)

lit. 'The Czech Social Democratic Party and the party ANO voted oppositely to their repeated public proclamations.'

(25) Figuriny byly použity tím nejpopisnějším způsobem, vlastně protikladně Sadeově nespoutané fantazii. (SYN V7)

lit. 'The manikins were used in a most prosaic way, or oppositely to Sade's unbridled fantasies.'

(26) Bulharsko je na tom srovnatelně s námi.

'Bulgaria is doing comparably well to us.'

Note that some adverbs (such as protikladně or priměreně below) can have complements of more than one form, as witnessed by (24) and (25) or (29) and (30) below.

There are several other adverbs that inherently express comparison and are typically followed by jako 'as' or než 'than', namely stejně 'just', podobně 'similarly', přesně 'exactly', obdobně 'similarly', opačně 'oppositely', obráceně 'backwards', rozdílně 'differently', identicky 'identically', jinak 'otherwise', nejinak 'likewise', jinde 'elsewhere', jinam 'elsewhere/away', jindy 'another time', odjinud 'from elsewhere', jinudy 'another way', jináč 'otherwise', and od(ni)kud jinud 'from (no)where else'. It is somewhat questionable whether or not these adverbs should be viewed as having valency properties. There are also expressions such as shodně $(s)$ 'consistently (with)', souhlasně (s) 'in agreement (with)', and úměrně $s$ 'proportionately', which can be viewed as secondary prepositions [17, pp. 43-44].

d) others: nezávisle ‘independently’, odděleně ‘separately’, přiměřně 'adequately’, loajálně 'loyally' 
(27) Šlechta a města nezávisle na státu vydávala správní předpisy.

'The nobility and the town issued administrative legislation independently of the state.'

(28) mundumugu vždycky bydlí a jí sám, odděleně od svého lidu

'the mundumugu always lives and dines alone, separately from his people'

(29) Totéž platí pro kotata, která maji být čilá přiměřeně věku.

'The same holds for kittens, which are supposed to be alert adequately to their age.'

(30) Určime, co by měl žák v TV přiměřeně $k$ jeho věku a výstupuim dle RVP ZV znát.

'We determine what the pupil should know in PE adequately to his age and the curriculum framework.'

(31) Když už státní zaměstnanci prece protestovali, tak loajálně ke státu v neděli odpoledne, jak tomu bylo 6. listopadu 1910 v Brné.

'When civil servants finally protested, they did so loyally to the state on a Sunday afternoon, which happened on November 6, 1910, in Brno.'

\subsection{Non-derived adverbs}

The adverbs pozdè 'late' and brzy (brzo) 'early' belong to this group, cf. the following examples:

(32) je príliš pozdě na jezevčiky s jejich důchodci, př́liš brzy na milence 'it's too late for dachshunds with their pensioners, and too early for lovers'

(33) zemrela príliš brzy na to, aby stihla na toto téma s dcerou promluvit 'she died too early to talk to her daughter about that'

(34) V̌̌as na to, aby pochopili, oč jde, pozdě na to, aby se jich to týkalo.

'Just in time to understand what was happening, too late for it to concern them.'

Ex. (34) suggests that včas should also be included as a valent adverb, albeit not non-derived.

\subsection{Predicative adverbs}

The SYN2015 data included the following predicative adverbs: potreba 'necessary'; lito 'sorry'; zapotřebi 'needed/necessary'; zataženo 'cloudy'; zima 'cold'; horko 'hot'; netřeba 'needless'; rušno 'busy'; zle 'sick'; mokro 'wet'; vlhko 'damp'; živo 'lively'; oblačno 'cloudy'; polojasno 'somewhat cloudy'; potřebi 'need' (e.g. nebylo potŕebi fantazie 'there was no need of imagination'); smutno 'sad'; sucho 'drought'; veselo 'merry'; parno 'hot'; pusto 'desert'; temno 'dark'; větrno 'windy'; teplo 'hot'; ticho 'silent'; (být) libo 'wish'. Considering examples such as (35), in which $s$ is misparsed as a daughter node of zataženo 'cloudy', it seems clear that these adverbs do not take complements. 
(35) Oba dva dny by mělo být zataženo s občasnými deštovými přeháňkami.

'On both of the days it should be cloudy with occasional showers of rain.'

Nevertheless, it is somewhat conspicuous that predicative adverbs referring to weather and the like quite systematically co-occur with locative (or, possibly, temporal) adjuncts, which was in fact noted as early as by Komárek [18, p. 23]. Similarly, predicative adverbs expressing physical sensations and internal states systematically co-occur with a dative form referring to the experiencer, as in (36), and modal predicative adverbs systematically co-occur with infinitives (and, in some cases, with nouns), as in (37):

(36) Občas se při tom přiotrávím acetonem a je mi potom zas nějakou dobu zle.

'Sometimes when doing it, I get poisoned with acetone and I feel sick for some time.'

(37) Je jenom zapotřebí promluvit lidem do srdce.

'It is necessary to touch people's hearts with your words.'

Based on that, the question of whether these adverbs really lack valency might arise. We believe that the predicative adverbs do not have valency properties; their systematic co-occurrence with a copula and a certain type of adjunct is, in our view, the result of the existence of independent constructions in the sense of Construction Grammar [19]. That is, we believe that there is for instance a construction (i.e. a Saussurean sign) with the form [[copula] [locative adjunct] [predicative adverb]], which systematically expresses the meaning of 'there is the specified kind of weather or external state in the specified area' and which licenses constructs such as (38). Postulating such a construction is in accord with the fact that the construction can be used somewhat productively, as witnessed by examples such as the following:

(38) když kvetly, bylo tam bílori̊žovo (SYN V7)

'when they were blooming, it was all white-pinkish there'

(39) v metropoli se začínaji rozkládat mrtvá těla a je tam neobyvatelno (SYN V7)

lit. 'in the capital dead bodies are starting to decompose and it is inhabitable there'

In ASSČ, predicative adverbs are marked by the word-class specification "př́sl. v prísudku," and their valency specification states the type of adjunct that typically co-occurs with the adverb; e.g., bilo '(all) white' has the valency specification (kde).

While we said that we do not consider predicative adverbs to have valency properties in the usual sense, there is one exception, found in SYN2015: libo, cf. the following example: 
(40) Je libo porci za deset krejcarů?

'Would you like a portion for ten pennies?'

Arguably, while libo is used in the same syntactic configuration as other predicative adverbs, it actually differs in that it takes a complement (porci in (40)).

\section{CONCLUSION AND DISCUSSION}

In this paper, we used two syntactically annotated corpora of Czech to extract a list of potentially valent adverbs in Czech. We manually discarded hundreds of candidates and arrived at several formal and semantic groups of valent adverbs, as presented above. There are some notoriously problematic issues, most notably concerning the fuzzy border between adverbs and prepositions. Words like navzdory 'notwithstanding' and kolem 'around', which are usually treated in terms of adverbpreposition homonymy, were not discussed here either even though they would certainly benefit from further investigation.

Finally, we would like to make three remarks. First, while we see nezávisle and other words discussed above as adverbs with valency, some linguistics treat e.g. nezávisle na 'idenpendently of/from' as a secondary preposition (cf. [20, p. 511] or [21, p. 47]). To give two further examples, while we included paralelně (cf. example 19), Kroupová [17, p. 42] includes paralelně s 'parallel to' as a secondary preposition with the lowest degree of conventionalization, and, for instance, Blatná [21, p. 47] includes úmérněs 'proportionately to' as a secondary preposition. ${ }^{5}$ We still included these as adverbs with valency based on our intuitions that the adverbs involved were still notably "adverby" (esp. when functioning as clause elements and not being delexicalized) and based on examples such as (41), in which úměrněs can hardly be viewed as a secondary preposition:

(41) Neschopnost uvěrit ve smrt roste př́mo úměrně s tím, jak se bliží.

'One's disbelief in death grows in proportion to its approach.'

Note, however, that this does not in fact exclude the possibility of viewing úměrněs $s$ as a secondary preposition in other contexts.

Second, it is typically assumed that derived words "inherit" the valency specification from their respective bases, an assumption especially common in noun valency studies; on argument inheritance see e.g. [22, p. 215]. This assumption is,

\footnotetext{
${ }^{5}$ Blatná [2, p. 47] lists all the following expressions as secondary prepositions: nalevo od 'left of', napravo od 'right of', nezávisle na 'independently of', paralelně s 'parallel to', shodně s 'consistently with', souběžněs 'parallel to', současněs 'simultaneously to', souhlasněs 'in agreement with', společně $s$ 'together with', spolu s 'together with', úměrně s 'proportionately to', úměrně $k$ 'proportionately to', zároveňs 'along with'.
} 
however, in fact problematic, and it is questionable whether we should specify the valency of derived words with or without recourse to derivation, as suggested by remarks made, among others, by Herbst [23, p. 267], Williams [24, p. 584], Allerton [5, p. 311], and Goldberg [25, p. 24], as summarized in Sláma [4, pp. 27-28]. While this issue is definitely beyond the scope of the present paper, it is still worth pointing out that the directional adverbs mentioned above suggest that the issue of inheritance is not as straightforward as it is usually assumed to be. While e.g. severně (od) 'north (of)' is usually described as a derivative of severní, the adverb does not seem to inherit the valency frame of the adjective but perhaps of the corresponding noun ( $\mathrm{na}$ sever od 'north of').

Third, related to the previous point is the question of the lexicographic treatment of adverbial valency: while the current practice in the ASSČ allows only deadjectival adverbs to have their valency specification $[16, \mathrm{p} .68]$ but also deals with predicative adverbs as if they had valency, it seems reasonable to conclude that some adverbs whose corresponding adjectives presumably lack valency properties (e.g. severnĕ) should be described as valent as well.

\section{ACKNOWLEDGEMENTS}

The work has been in part supported by the LINDAT/CLARIN and LINDAT/ CLARIAH-CZ projects of Ministry of Education, Youth and Sports of the Czech Republic (LM2015071 and LM2018101).

\section{References}

[1] Thompson, S., and J. Hopper (2001). Transitivity, clause structure, and argument structure: Evidence from conversation. In J. Bybee and P. Hopper (eds.), Frequency and the Emergence of Linguistic Structure, pages 27-60. Amsterdam, John Benjamins.

[2] Spevak, O. (2014). Editor's foreword. In O. Spevak (ed.), Noun Valency, ix-xiii. Amsterdam \& Philadelphia, John Benjamins Publishing Company.

[3] Taylor, J. R. (2015). Prototype effects in grammar. In E. Dabrowska \& D. Divjak (eds.), Handbook of Cognitive Linguistics, pages 562-579. Berlin; Boston, De Gruyter Mouton.

[4] Sláma, J. (2018). The prepositional phrase with the preposition at as a valency complement of nouns. MA thesis. Prague, Department of English Language and ELT Methodology.

[5] Allerton, D. J. (2006). Valency Grammar. In K. Brown (ed.), Encyclopedia of Language \& Linguistics, pages 13, 301-314. $2^{\text {nd }}$ ed. Amsterdam, Elsevier.

[6] Tesnière, L. (1959). Éléments de syntaxe structurale. Paris, Klincksieck.

[7] Lees, R. B. (1960). The Grammar of English Nominalization. The Hague, Mouton.

[8] Matthews, P. H. (1981). Syntax. Cambridge, Cambridge University Press.

[9] Matthews, P. H. (1997). The Concise Oxford Dictionary of Linguistics. Oxford, Oxford University Press. 
[10] Crystal, D. (2003). A Dictionary of Phonetics and Linguistics. $5^{\text {th }}$ ed. Oxford, Blackwell.

[11] Matthews, P. H. (2007). The scope of valency in grammar. In T. Herbst \& K. Götz-Votteler (eds.), Valency: Theoretical, Descriptive and Cognitive Issues, pages 3-14. Berlin; New York, Mouton de Gruyter.

[12] Francis, G., S. Hunston, and E. Manning (1996). Collins Cobuild Grammar Patterns 1: Verbs. London, HarperCollins.

[13] Francis, G., S. Hunston, and E. Manning (1998). Collins Cobuild Grammar Patterns 2: Nouns and Adjectives. London, HarperCollins.

[14] Karlík, P., and P. Biskup (2017). Adverbium. In P. Karlík, M. Nekula, and J. Pleskalová (eds.), CzechEncy - Nový encyklopedický slovník češtiny. Brno, Masarykova univerzita. Accessible at: <https: //www. czechency.org/slovnik/ADVERBIUM>.

[15] Panevová, J. (1998). Ještě k teorii valence. Slovo a slovesnost 59(1), pages 1-14.

[16] Kochová, P., and Z. Opavská (eds.) (2016). Kapitoly z koncepce Akademického slovníku současné češtiny. Praha, Ústav pro jazyk český AV ČR.

[17] Kroupová, L. (1985). Sekundární předložky v současné spisovné češtině. Praha, ÚJČ ČSAV.

[18] Komárek, M. (1954). K otázce predikativa (kategorie stavu) v češtině. In Sborník VŠ pedagogické v Olomouci (Jazyk a literatura), pages 7-25. Praha, Státní pedagogické nakladatelství.

[19] Hoffmann, T., and G. Trousdale (2013). The Oxford Handbook of Construction Grammar. New York, Oxford University Press.

[20] Štícha, F. (ed.). Akademická gramatika spisovné češtiny. Praha, Academia.

[21] Blatná, R. (2006). Víceslovné předložky v současné češtině. Praha, Nakladatelství Lidové noviny.

[22] Booij, G. (2007). The Grammar of Words. Oxford, Oxford University Press.

[23] Herbst, T. (1988). A valency model for nouns in English. Journal of Linguistics, 24(2), pages 265-301.

[24] Williams, E. (1991). Meaning Categories of NPs and Ss. Linguistic Inquiry 22(3), pages 584 587.

[25] Goldberg, A. E. (2006). Constructions at Work. Oxford, Oxford University Press. 